Article

\title{
Seasonal and Diurnal Thermal Performance of a Subtropical Extensive Green Roof: The Impacts of Background Weather Parameters
}

\author{
Lilliana L. H. Peng ${ }^{1, *}$ and C. Y. Jim ${ }^{2}$
}

1 Department of Urban and Rural Planning, College of Architecture, Nanjing Tech University; No. 30 Puzhu Road, Nanjing 210094, China

2 Department of Geography, The University of Hong Kong, Pokfulam Road, Hong Kong, China; E-Mail: hragjcy@hku.hk

* Author to whom correspondence should be addressed; E-Mail: plhblue@126.com or plhblue@njtech.edu.cn; Tel.: +86-189-1398-4921; Fax: +86-25-5813-9090.

Academic Editor: Marc A. Rosen

Received: 15 July 2015 / Accepted: 7 August 2015 / Published: 14 August 2015

\begin{abstract}
Most studies explored green-roof thermal effects on a few hot summer days based on short-term monitoring data. Few studies investigated the seasonal and diurnal patterns of thermal performance and associated weather effects. This research aims to address the following two questions: (1) how green-roof thermal performance varies with different season and time; and (2) to what extent can thermal performance be predicted by background weather parameters? A retrofitted extensive green roof was established on the top of a railway station in subtropical Hong Kong. Monitoring data covering a two-year period, one year before roof greening and one year after, were collected and analyzed. Results indicated notable seasonal and diurnal patterns of green-roof thermal performance. It exhibited cooling effects in spring, summer and fall, but warming effects in winter. The cooling effects were more pronounced in summer than spring and fall, on sunny days than rainy and cloudy days, and in nighttime than daytime. Air temperature, relative humidity, wind speed, solar radiation, and soil moisture could explain $83.6 \%-86 \%$ of the thermal effects' variation. The multiple-regression models based on the five weather variables established in this study provide an uncomplicated and direct approach to predict the thermal performance of similar extensive green roofs in subtropical areas.
\end{abstract}


Keywords: green roof; thermal performance; weather effects; seasonal effect; temporal pattern

\section{Introduction}

The combined effects of global warming and urban heat island (UHI) effects have caused a large amount of energy use and greenhouse gas (GHG) emissions, as well as thermal discomfort in urban areas [1]. Designing cities in a climate-conscious way not only contributes to UHI mitigation and urban sustainability, but also offers cities opportunities to address global issues at the local level [2]. Giving the large amount of worldwide energy use associated with a building's life cycle, various design strategies have been proposed to improve a building's energy efficiency [3]. Among these strategies, cool roofs have received much research attention due to the notable thermal benefits. Continuous monitoring and simulation studies have been involved to evaluate the impacts of cool roofs on surface and air temperature, the number and frequency of extreme weather conditions, energy consumptions and GHG emissions [4-6].

Green roofs present one important category of the cool-roof family. The multiple layers of the green-roof structure can protect building roofs from direct solar radiation in the summer, cutting heat flux entering the interior spaces and saving electrical energy for cooling. The evapotranspiration from vegetation and soil can cool the ambient air and improve microclimate, triggering "cool-island" effects $[7,8]$. The literature has generated extensive studies on green-roof thermal effects in various climatic contexts. These studies roughly fall into three categories in terms of study approaches and objectives, including: (1) on-site monitoring to investigate green-roof impacts on summer temperature parameters and building heat flux patterns [9-22]; (2) dynamic energy modeling to analyze the heat and moisture processes within the green-roof layers and identify key influential factors [23-28]; and (3) building energy simulation or meso-scale climatic modeling to predict the cooling and energy effects of individual or multiple green-roof installations [29-34]. The studies have reported that green roofs can reduce summer daily peak surface temperature by $15{ }^{\circ} \mathrm{C}-45^{\circ} \mathrm{C}$ and peak air temperature by up to $5{ }^{\circ} \mathrm{C}$. Energy demand can be cut by $8 \%-80 \%$ for individual buildings, depending on background climatic conditions and roof insulation levels [35]. When applied on a city scale, green roofs may reduce the ambient temperature between $0.3{ }^{\circ} \mathrm{C}-3{ }^{\circ} \mathrm{C}[36]$.

These studies, however, have largely focused on green-roof thermal effects in summer daytime, while ignoring their seasonal and diurnal variability and underlying weather effects. It has been widely reported that the UHI effect display notable seasonal and diurnal patterns with varying background weather parameters, such as radiation, humidity, temperature, and wind speed [37]. These weather factors also exert significant influence on the heat and water dynamics of green-roof systems [7,19]. Evaluation of the temporal variations of green-roof thermal performance with respect to weather effects enables a deep and comprehensive understanding of its role as a UHI mitigation measure. Speak et al. [38] compared the seasonal and diurnal cooling effects between a healthy green roof and another damaged green roof with exposed bare substrate. Results found that both green roofs display remarkable temporal variations in cooling effects. However, this study provides limited reference for the performance of subtropical 
green roofs as it was conducted in a temperate climate zone. This study aims to answer the following two questions that have not been adequately addressed: (1) How green-roof thermal effects vary with seasons across a year, and with time across a day, in humid subtropical areas? (2) To what extent can thermal effects be predicted by background weather parameters? The research objectives are twofold: (1) evaluate the daytime and nocturnal modification of main weather parameters by green roofs for different season-cum-weather conditions; and (2) investigate the effects of key weather parameters on green-roof thermal performance based on multiple-regression models.

\section{Study Area and Methods}

\subsection{Study Area}

Hong Kong is situated at the south coast of China, at $22^{\circ} \mathrm{N}$ latitude and $114^{\circ} \mathrm{E}$ longitude with a typical humid-subtropical climate influenced by the dominating Asian monsoon climatic system. It has four distinct seasons with varying temperature, rainfall, and humidity features. Spring is the most humid and cloudiest time of the year, with an average temperature of about $22{ }^{\circ} \mathrm{C}$. Summer is hot and humid from late April to September, with August the hottest month often exceeding $33{ }^{\circ} \mathrm{C}$. Fall is the sunniest and pleasant season through the year when there is a large decrease in rainfall and temperature, compared to summer. Winter is relatively dry and mild, running from January to February, with average temperature above $10^{\circ} \mathrm{C}$.

Hong Kong is characterized as one of the most densely-built cites in the world. The compact urban morphology, in conjunction with the extreme shortage of ground-level green spaces, has resulted in an intense UHI effect. It has been reported that the UHI intensity in Hong Kong ranges from $1.5^{\circ} \mathrm{C}$ to $3.8^{\circ} \mathrm{C}$ in terms of air temperature based on 19-year daily and hourly meteorological data from typical urban and rural weather stations. The UHI intensity demonstrates notable diurnal and seasonal variations, stronger in nighttime than daytime, with a maximum value in winter [39]. Roof greening has been proposed as an effective tool to compensate for the scarcity of ground-level greenery and alleviate the thermal and environmental plight [40-42]. The public services provided by this doorstep green oasis can also improve urban sustainability and quality of life [43].

\subsection{Experimental Design}

The extensive green roof was retrofitted in July 2009 on a two-storey railway station located in a suburban district named Tai Po in Hong Kong. The station is surrounded by low-rise public and commercial buildings and, thus, is free from the influence of shadows or reflected radiation from adjacent buildings or trees. The large flat rooftop is composed of several parcels with different elevations and areas. This study enlists the largest plot (the experimental site with green roof) which is square in shape with an area of $484 \mathrm{~m}^{2}$. A nearby plot (the control site with original bare roof), with an area of $106 \mathrm{~m}^{2}$, provides a baseline for comparison. The green roof was installed on the reinforced-concrete flat-roof protected by a waterproofing membrane, thermal insulation, screed, and cement tiles. A proprietary multiple-layer green-roof system (Nophadrain, Kirkrade, The Netherlands) was laid directly on the concrete tile with a $2 \%$ gradient to shed drainage water. From bottom to top, it contains five layers: plastic 
(polyethylene) root barrier, plastic (high impact polystyrene) drainage, geotextile filter, rockwool water retention, and growing medium (Table 1).

A perennial, herbaceous and evergreen vine, Arachis pintoi (Perennial Peanut), was chosen for its vigorous growth and formation of a tight and complete green cover. It is a tropical low-growing (about $20 \mathrm{~cm}$ thick), ground-hugging, non-twining, and nitrogen-fixing legume. Its ornamental value is attributed to the continuously verdant green foliage and many dainty golden-yellow flowers presented for seven warm months in a year. Vigorous stem cuttings were spread at a high density on the prepared soil surface. The vigorous plant was able to achieve $100 \%$ site coverage in three months of growth in the warm season. Thereafter, a continuous green mantle has been maintained with gradual addition of new stems and foliage to enhance the thermal insulation effect. An automatic sprinkler irrigation system provided supplementary water supply at $5 \mathrm{~L} / \mathrm{m}^{2} /$ day, sustaining an average soil moisture content of about $0.3 \mathrm{~m}^{3} / \mathrm{m}^{3}$. Watering was regulated by a rainfall detector to stop the pump when cumulative antecedent rainfall exceeded $10 \mathrm{~mm}$.

Table 1. Physical properties of the green-roof multiple-layered components.

\begin{tabular}{|c|c|c|c|}
\hline \multicolumn{2}{|c|}{ Vertical component } & \multirow[b]{2}{*}{ Screed and concrete } & \multirow{2}{*}{$\begin{array}{c}\text { Thickness } \\
\text { (mm) }\end{array}$} \\
\hline \multirow{4}{*}{$\begin{array}{l}\text { Reinforced } \\
\text { roof deck }\end{array}$} & Roof slab & & \\
\hline & Waterproof membrane & Two-layer torched-applied modified bitumen assembly & 0.5 \\
\hline & Insulation & Extruded polystyrene & 50 \\
\hline & Concrete tile & Screed and concrete & 200 \\
\hline \multirow{6}{*}{$\begin{array}{l}\text { Extensive } \\
\text { green roof }\end{array}$} & Root barrier & Polyethylene & 0.5 \\
\hline & Drainage & High impact polyethylene & 25 \\
\hline & Filter & Geo-textile & 0.5 \\
\hline & Water storage & Rockwool & 40 \\
\hline & Growing medium & Decomposed granite and compost & 70 \\
\hline & Vegetation & Perennial Peanut & 200 \\
\hline
\end{tabular}

Five background weather parameters were measured (Figure 1), including solar radiation (SR), ambient air temperature $\left(T_{a}\right)$, relative humidity (RH), wind speed (WS), and substrate moisture (SM). Three sets of thermal-performance indicators were monitored, including air temperature at $10 \mathrm{~cm}$ and $160 \mathrm{~cm}$ level ( $T_{10}$ and $\left.T_{160}\right)$, relative humidity at $10 \mathrm{~cm}$ and $160 \mathrm{~cm}$ level $\left(\mathrm{RH}_{10}\right.$ and $\left.\mathrm{RH}_{160}\right)$, and surface temperature at the vegetation surface $\left(T_{v}\right)$ and concrete tile $\left(T_{t}\right)$. All sensors were synchronized to take readings at 15-min interval, and measurements were stored in stand-alone data loggers kept in weatherproof cabinets. Two types of data loggers were installed (Figure 2), including a HOBO industrial logger (U12-008) connected with infrared temperature sensors for monitoring vegetation canopy surface temperature, a micro station logger (H21-002) connected with anemometer for measuring wind speed, and a weather station for the record of temperature, humidity, solar radiation, and moisture data. Collected data were exported to PC every month via a direct USB interface. 


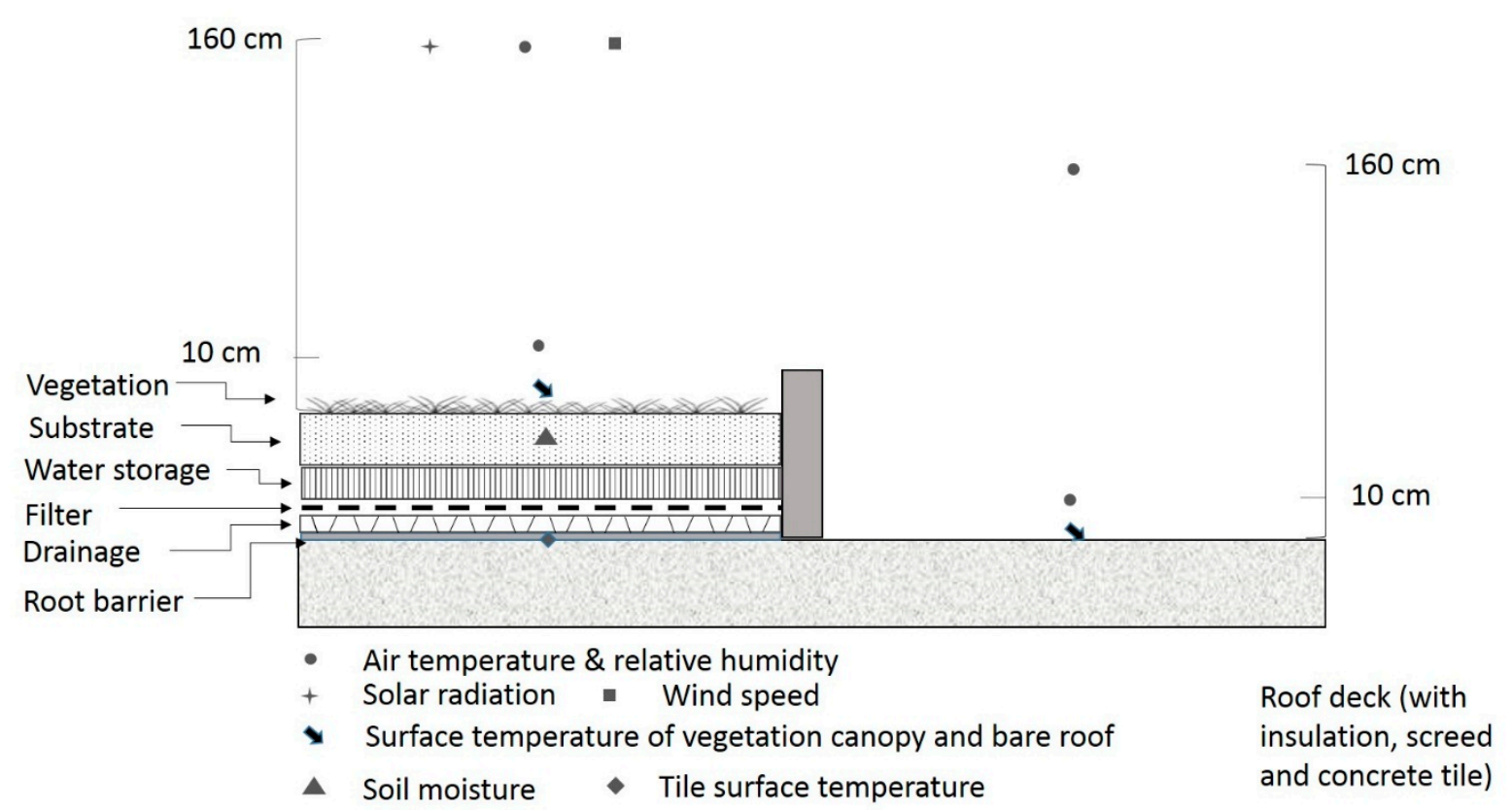

Figure 1. Position and height of environmental monitoring sensors at green roof experimental plot (site A) and bare roof control plot (site Z).

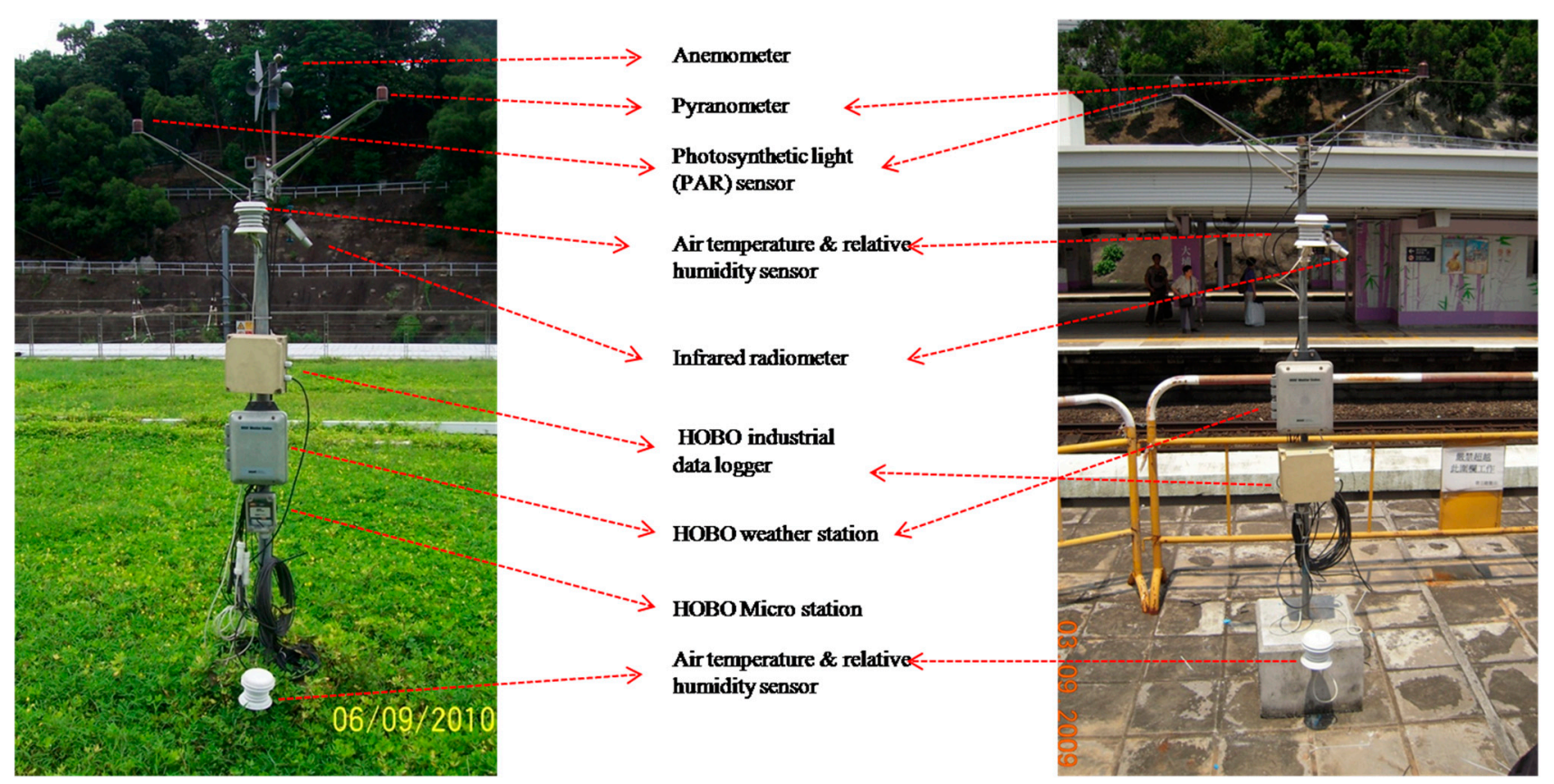

Figure 2. Sensor and logger positions to measure the above-surface environmental parameters (left: green roof; right: control bare roof).

\subsection{Data Collection}

Monitoring data from 1 June 2008 to 21 May 2009 before the installation of green roof and 7 August 2009 to 30 September 2011 after the roof greening were used to perform the analyses. Both sessions permit data coverage of the four seasons: spring from 1 March to 31 May, summer from 1 June to 
30 September, fall from 1 October to 31 December, and winter from 1 January to 28 February. Three weather types, namely sunny, rainy, and cloudy were differentiated for each season. Table 2 presents the general range of daily sunshine hours, cloud amount, and rainfall for each weather category.

The four seasons, in conjunction with three weather types, generates 12 season-cum-weather scenarios which offer a comprehensive coverage of weather conditions over a year (abbreviation of each weather type is given in Table 3). The winter-rainy scenario was removed from the analysis as it is not a typical weather type of Hong Kong.

Table 2. Criteria for selection of typical weather types.

\begin{tabular}{lccc}
\hline & Sunshine hours & Cloud amount (\%) & Rainfall (mm) \\
\hline Sunny & $4-11$ & $<80$ & 0 \\
Cloudy & $0-4$ & $>90$ & 0 \\
Rainy & 0 & $80-90$ & $>10$ \\
\hline
\end{tabular}

\subsection{Data Processing}

\subsubsection{Thermal-Effect Indicators}

Daytime values (DT) averaged from 12:00 h-16:00 h, and nighttime values (NT) averaged from 20:00 h-24:00 $\mathrm{h}$ of $\mathrm{T}_{10}, \mathrm{~T}_{160}, \mathrm{RH}_{10}, \mathrm{RH}_{160}, T_{v}$, and $T_{t}$ were derived as thermal indicators.

\subsubsection{Background Weather Variables}

DT and NT of five weather variables, including solar radiation (SR), ambient air temperature $\left(T_{a}\right)$, relative humidity $(\mathrm{RH})$, and substrate moisture $(\mathrm{SM})$ were derived to represent the background weather conditions. Table 3 presents all the symbols and abbreviations used in this paper.

Table 3. Symbols and measurement units used in this paper.

\begin{tabular}{|c|c|c|}
\hline Symbol & Unit & Explanation \\
\hline & & Study site \\
\hline A & na & Experimental plot after green roof installation \\
\hline $\mathrm{B}$ & na & Experimental plot before green roof installation \\
\hline Z & na & Control (bare roof) plot \\
\hline \multicolumn{3}{|c|}{ Monitoring thermal-effect indicators } \\
\hline $\mathrm{T}_{\mathrm{t}}$ & ${ }^{\circ} \mathrm{C}$ & Concrete tile surface temperature \\
\hline $\mathrm{T}_{\mathrm{v}}$ & ${ }^{\circ} \mathrm{C}$ & Vegetation canopy surface temperature \\
\hline $\mathrm{T}_{10}$ & ${ }^{\circ} \mathrm{C}$ & Air temperature at $10 \mathrm{~cm}$ height \\
\hline $\mathrm{T}_{160}$ & ${ }^{\circ} \mathrm{C}$ & Air temperature at $160 \mathrm{~cm}$ height \\
\hline $\mathrm{RH}_{10}$ & ${ }^{\circ} \mathrm{C}$ & Relative humidity at $10 \mathrm{~cm}$ height \\
\hline $\mathrm{RH}_{160}$ & ${ }^{\circ} \mathrm{C}$ & Relative humidity at $160 \mathrm{~cm}$ height \\
\hline \multicolumn{3}{|c|}{ Derived thermal-effect indicators } \\
\hline DT & ------ & Daytime mean from $12: 00 \mathrm{~h}$ to $16: 00 \mathrm{~h}$ \\
\hline NT & ------ & Nighttime mean from 20:00 $\mathrm{h}$ to $00: 00 \mathrm{~h}$ \\
\hline
\end{tabular}


Table 3. Cont.

\begin{tabular}{ccc}
\hline Symbol & Unit & Explanation \\
\hline SPS & & Season-cum-weather scenarios \\
SPR & ----- & Spring sunny \\
SPC & ----- & Spring rainy \\
SUS & ----- & Spring cloudy \\
SUR & ----- & Summer sunny \\
SUC & ----- & Summer rainy \\
FLS & ----- & Summer cloudy \\
FLR & ----- & Fall sunny \\
FLC & ----- & Fall rainy \\
WTS & ----- & Fall cloudy \\
WTC & ----- & Winter sunny \\
& ----- & Winter cloudy \\
$\mathrm{T}_{\mathrm{a}}$ & ${ }^{\circ} \mathrm{C}$ & Background weather variables \\
RH & $\%$ & Air temperature \\
SR & $\mathrm{Wm}^{-2}$ & Relative humidity \\
$\mathrm{WS}$ & $\mathrm{ms}^{-1}$ & Solar radiation \\
SM & $\mathrm{m}^{3} \mathrm{~m}^{-3}$ & Wind speed \\
\hline & & Substrate moisture \\
\hline
\end{tabular}

\subsection{Data Analysis}

\subsubsection{Independent T-test}

Independent T-test was conducted to study the magnitude and significant level of temperature and humidity modifications due to green-roof installation. Comparisons were made between the before (site B) and after session (site A) for each season-cum-weather scenario in terms of DT and NT difference between the green (site A) and bare roof (site Z).

\subsubsection{Multiple Regression Analysis}

Multiple regression analysis was adapted to explore how significantly the green-roof thermal effects can be determined by background weather condition. The green-bare differences in $T_{v}, \mathrm{~T}_{10}, \mathrm{RH}_{10}$, and $T_{t}$ were used as thermal-effect indicators. The five background weather variables were used as independent variables in the model. For each thermal-effect indicator, two regression models (DT and NT) were constructed to explore the weather effects on daytime and nighttime thermal performances, respectively. DT models examined all the five background weather variables, while the NT ones excluded SR, as it has no variation in the nighttime. Due to correlations among the weather variables, we used stepwise regressions in all models, which added the independent variables one by one and only keeps those that contribute to the model significantly with a threshold of $90 \%$ as the final independent variables. 


\section{Seasonal and Diurnal Patterns of Green-roof Thermal Effects}

\subsection{Overall Assessment}

Generally, thermal effects are notable in the nighttime but less so in the daytime (Table 4). Of the four seasons, fall exhibits the smallest thermal effects as it has the least number of significant modifications in both daytime and nighttime. Within each season, sunny weather conditions tend to have a larger number of significant modifications than cloudy and rainy scenarios. Of the six thermal effects indicators, the modifications on temperature parameters are more notable than relative humidity at the same level. The closer to the green roof, the larger the temperature change.

Table 4. Modification of key thermal indicators after roof greening.

\begin{tabular}{|c|c|c|c|c|c|c|c|}
\hline & & $T_{10}$ & $T_{160}$ & $\mathrm{RH}_{10}$ & $\mathrm{RH}_{160}$ & $T_{t}$ & $\mathbf{T}_{\mathbf{v}}$ \\
\hline \multirow{11}{*}{ Daytime } & SPS & $-0.6^{* *}$ & -0.2 & $0.8^{*}$ & $-5.3^{* *}$ & $-4.1^{* *}$ & $1.6^{* *}$ \\
\hline & SPR & $-1.1^{* *}$ & -0.4 & $3.2^{*}$ & $-2.6^{* *}$ & -0.7 & 0.4 \\
\hline & SPC & $-0.5^{* *}$ & -0.3 & 0.9 & $-4.1^{* *}$ & $-2.1^{* *}$ & $1.0^{* *}$ \\
\hline & SUS & $-0.9^{* *}$ & $-0.7^{* *}$ & $2.7^{* *}$ & $-3.6^{* *}$ & $-7.9^{* *}$ & $2.2^{* *}$ \\
\hline & SUR & $-1.3^{* *}$ & $-0.5^{* *}$ & $4.4^{* *}$ & $-2.1^{* *}$ & $-1.1^{* *}$ & $1.8^{* *}$ \\
\hline & SUC & -0.8 & -0.2 & 1.5 & $-4.7^{* *}$ & -1.4 & 2.0 \\
\hline & FLS & -0.2 & 0.1 & $-1.1^{* *}$ & $-5.7^{* *}$ & $-5.8^{* *}$ & $1.7^{* *}$ \\
\hline & FLR & -0.6 & -0.1 & 1.5 & $-3.4^{* *}$ & 1.3 & 0.2 \\
\hline & FLC & $-0.6^{*}$ & 0.1 & 0.4 & $-5.2^{* *}$ & $-2.9^{* *}$ & 0.3 \\
\hline & WTS & $0.8^{* *}$ & $0.3^{* *}$ & $-3.2^{* *}$ & $-6.2^{* *}$ & $-4.3^{* *}$ & $2.7^{* *}$ \\
\hline & WTC & $0.5^{* *}$ & $0.6^{* *}$ & $-2.4^{* *}$ & $-6.1^{* *}$ & $-0.7^{* *}$ & $2.1^{* *}$ \\
\hline \multirow{11}{*}{ Nighttime } & SPS & $-1.6^{* *}$ & $-0.5^{* *}$ & $3.4^{* *}$ & $-3.5^{* *}$ & $2.7^{* *}$ & $0.3^{* *}$ \\
\hline & SPR & $-1.3^{* *}$ & $-0.2^{*}$ & $3.5^{* *}$ & $-2.6^{* *}$ & $2.1^{* *}$ & $0.6^{* *}$ \\
\hline & SPC & $-1.1^{* *}$ & $-0.2^{* *}$ & $2.1^{* *}$ & $-3.8^{* *}$ & $2.0^{* *}$ & $0.6^{* *}$ \\
\hline & SUS & $-2.9^{* *}$ & $-0.6^{* *}$ & $7.9^{* *}$ & $-3.0^{* *}$ & $0.9^{* *}$ & $2.3^{* *}$ \\
\hline & SUR & $-2.3^{* *}$ & $-0.7^{* *}$ & $7.3^{* *}$ & $-1.1^{* *}$ & $0.8^{* *}$ & $2.0^{* *}$ \\
\hline & SUC & $-2.2^{* *}$ & $-0.6^{*}$ & $5.6^{* *}$ & $-2.7^{* *}$ & $-0.2^{* *}$ & 2.6 \\
\hline & FLS & $-1.9^{* *}$ & $-0.4^{* *}$ & $3.7^{* *}$ & $-3.3^{* *}$ & $1.3^{* *}$ & $-0.4^{* *}$ \\
\hline & FLR & $-1.2^{*}$ & -0.1 & 2.9 & $-3.2^{* *}$ & $3.0^{*}$ & -0.4 \\
\hline & FLC & $-1.2^{* *}$ & -0.1 & $2.0^{*}$ & $-4.3^{* *}$ & 0.7 & -0.3 \\
\hline & WTS & $-1.5^{* *}$ & $-0.3^{* *}$ & $2.8^{* *}$ & $-3.5^{* *}$ & $2.0^{* *}$ & $0.8^{* *}$ \\
\hline & WTC & $-0.5^{* *}$ & 0.2 & -0.2 & $-4.7^{* *}$ & $1.2^{* *}$ & $1.2^{* *}$ \\
\hline
\end{tabular}

${ }^{*}$ The modification is significant at 0.05 level. ${ }^{* *}$ The modification is significant at 0.01 level.

\subsection{Air Temperature}

Figure 3 shows the air temperature change after roof greening for each season-cum-weather scenario. Positive values denote temperature increase, and negative values denote decrease. Generally, spring, summer, and fall record cooling effects (temperature reduction) in both daytime and nighttime, whereas winter only experiences nocturnal cooling with a slight temperature rise in daytime. The dominant cooling effects through the year can be attributed to the warm climatic conditions in subtropical areas 
which sustains high evaporation rate throughout the year. Winter warming can be explained by the trap of heat in the vegetation canopy which augments the near surface ambient temperature.

The three cooling seasons (spring, summer, and fall) share a similar spatial and temporal temperature reduction pattern, with nocturnal cooling being stronger than daytime, and $T_{10}$ greater than $\mathrm{T}_{160}$ in terms of both magnitude and significance coefficient. For example, the nocturnal $T_{10}$ reduction is significant at the 0.01 level for all season-weather types, whereas significant reduction of daytime $\mathrm{T}_{10}$ is only restricted to SPS, SPR, SPC, SUS, SUR, FLC, WTS, and WTC. The difference between daytime and nighttime $T_{10}$ reduction ranges from $0.2{ }^{\circ} \mathrm{C}-2{ }^{\circ} \mathrm{C}$, with a maximum value on sunny summer days.

The three seasons also demonstrate a similar vertical pattern of cooling effects. The closer to the ground, the greater the air temperature reductions. $T_{10}$ reduction is only insignificant $(p>0.05)$ for daytime SUC, FLS, and FLC, while at $\mathrm{T}_{160}$ the insignificant reduction is extended to daytime SPS, SPR, SPC, FLC, and nighttime FLR, FLC, and WTC. The temperature reduction ranges from $0.2{ }^{\circ} \mathrm{C}-0.9^{\circ} \mathrm{C}$, and $1.1{ }^{\circ} \mathrm{C}-2.9{ }^{\circ} \mathrm{C}$ for daytime and nighttime $\mathrm{T}_{10}$, comparing with $0.2{ }^{\circ} \mathrm{C}-0.6{ }^{\circ} \mathrm{C}$ and $0.1{ }^{\circ} \mathrm{C}-0.6{ }^{\circ} \mathrm{C}$ for equivalent values of $T_{160}$. The divergence in $\mathrm{T}_{10}$ and $\mathrm{T}_{160}$ reduction demonstrate the "distance attenuation effect" of green-roof thermal performance. At the $10 \mathrm{~cm}$ level, both shading and evaporative cooling effects can bring down $T_{10}$, while at the $160 \mathrm{~cm}$ level the temperature reduction is only due to cool air advection from the near surface.
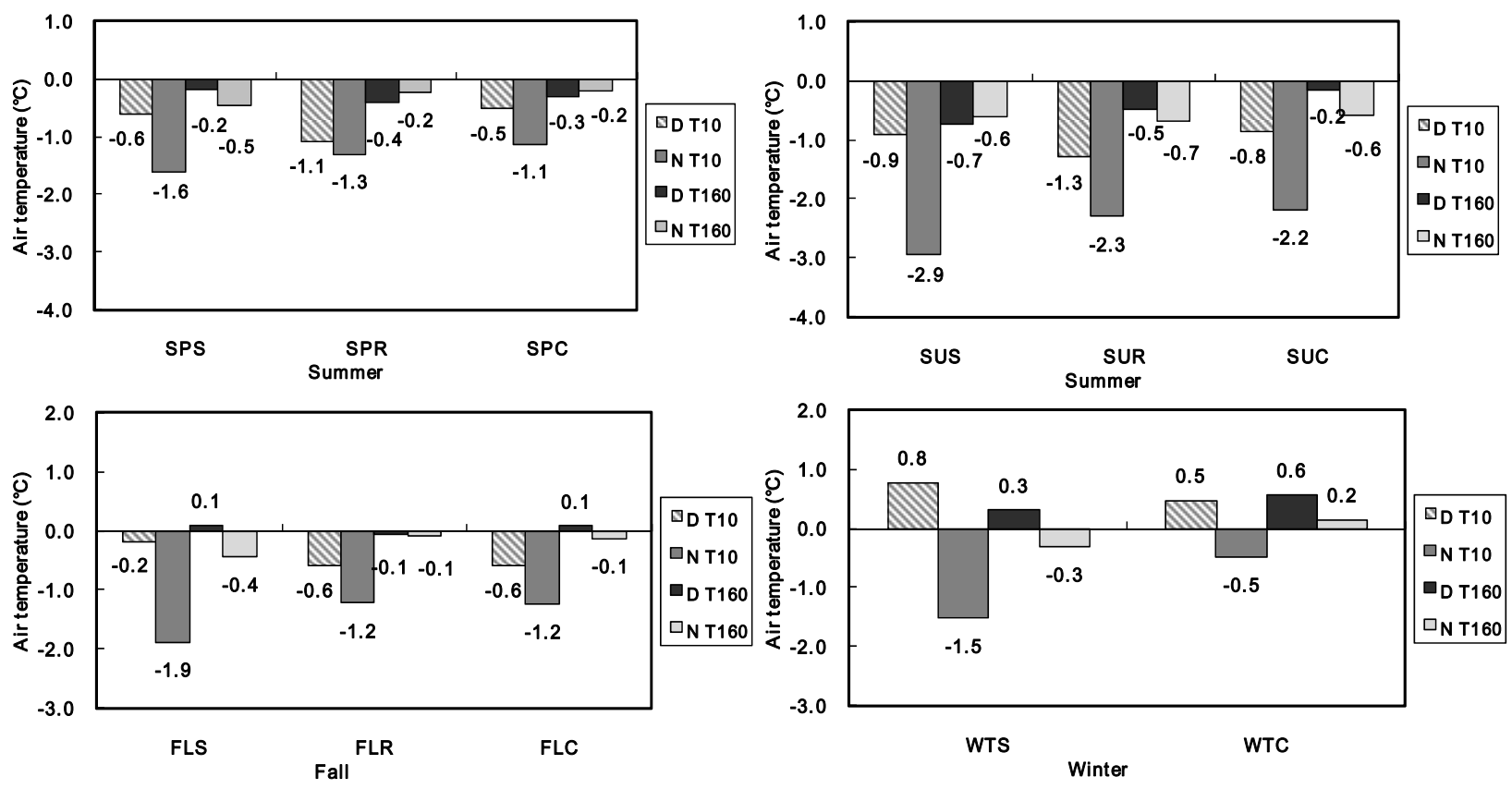

Figure 3. Modification of ambient air temperature after roof greening for the four seasons.

Seasonal variations were observed in terms of cooling intensity. Of the three cooling seasons, summer generally has a more remarkable cooling magnitude than spring and fall, when comparing equivalent temperature indicators among the three. For example, the reduction in $T_{10}$ of sunny-summer daytime is $0.9{ }^{\circ} \mathrm{C}$, comparing with $0.6{ }^{\circ} \mathrm{C}$ and $0.2{ }^{\circ} \mathrm{C}$ of equivalent values in spring and fall, respectively. The sunny-summer nocturnal cooling at $\mathrm{T}_{10}$ can reach $2.9^{\circ} \mathrm{C}$, while the numbers for spring and summer are $1.6^{\circ} \mathrm{C}$ and $1.9^{\circ} \mathrm{C}$, respectively. 
Within each season, the cooling effects are notably higher on sunny days, with similar magnitude on rainy and cloudy days. On sunny days, the bare roof surface is heated across the day, which further warms the near-surface air by strong sensible heat flux. While on the green roof, the high solar radiation combined with high air temperature can help sustain a large evaporation rate to enhance cooling. The equal cooling intensity during rainy and cloudy conditions might be explained by the similar temperature background.

\subsection{Relative Humidity}

The "wet island" effects of green spaces characterized by the increase of ambient humidity above the vegetation canopy are generally concurrent with their "cool-island" effects, both owing to the evapotranspiration process. Thus, evaluation of ambient humidity changes after roof greening can inform evaporative cooling effects of the green roof.
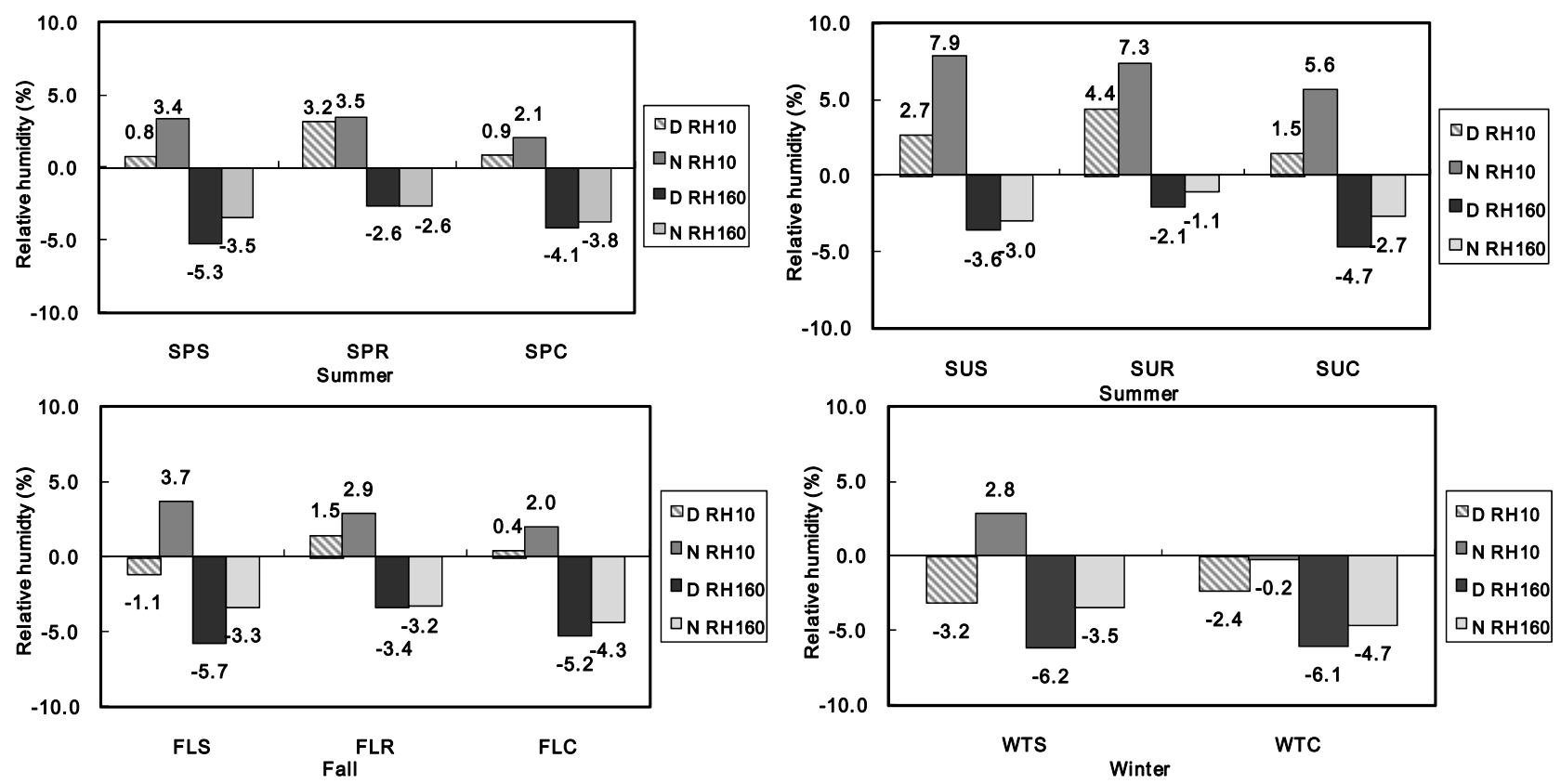

Figure 4. Modification of relative humidity after roof greening for the 11 season-cum-weather scenarios.

Similar as $T_{10}$, RH demonstrate notable seasonal, diurnal, and vertical patterns (Figure 4). In spring, summer, and fall, $\mathrm{RH}_{10}$ is significantly increased $(p<0.01)$ during both daytime and nighttime except FLS, reflecting enhanced evaporation in the three seasons. Summer has a larger increase than spring and fall, with the greatest rise in nocturnal sunny summer days at $7.9 \%$, contrasting with equivalent $3.4 \%$ and $3.7 \%$ in spring and fall, respectively. This indicates the highest evaporation during summer when solar radiation and air temperature peak. The winter season shows a reverse pattern with decreased $\mathrm{RH}_{10}$ during all weather conditions, reflecting suppressed evaporation during the cold season.

The diurnal pattern of $\mathrm{RH}_{10}$ shows similarity among spring, summer, and fall that the nighttime $\mathrm{RH}_{10}$ increase was generally $1 \%-5 \%$ higher than that of the daytime, with maximum diurnal variation on sunny summer days. The higher nocturnal $\mathrm{RH}_{10}$ increase corresponding with a similar diurnal pattern of $\mathrm{T}_{10}$ modification further confirms that green-roof cooling effects are mainly achieved in the nighttime. 
In contrast to $\mathrm{RH}_{10}, \mathrm{RH}_{160}$ is significantly reduced after roof greening for all the season-cum-weather scenarios. The vertical divergence of modifications in air temperature and relatively humidity after roof greening suggest that the cooling effects of extensive green roofs decrease with increasing distance from the roof surface, and might be marginal at a certain height.

\subsection{Canopy Surface Temperature $\left(T_{v}\right)$}

Surface temperature modification is a major indicator for green-roof thermal effects. $T_{v}$ affects sensible heat flux and long-wave radiation to the air, hence determining the magnitude of UHI mitigation. Contrary to expectations, most $T_{v}$ parameters were significantly increased after roof greening, with a higher increase on sunny days than rainy and cloudy days. The vegetation canopy anomaly might be explained by the following reasons: (1) the control bare roof in this study contains materials like asbestos which has high thermal capacity to sustain a relatively low surface temperature even without greening. The existing low surface temperature of the control roof render limited temperature reductions after roof greening; (2) the plants of the extensive green roof form a little dense tussock of short stems and tiny leaves as a cushion, which enhances friction when wind blows over the vegetation surface, resulting in a static wind layer known as the boundary layer. The leaves are warmed by the sun and most heat is trapped due to static air, contrasting to radiative cooling on the bare roofs during the daytime; and (3) the lower albedo of vegetation leaves, and feeble evaporation due to moisture exhaustion in the early afternoon, might also account for it in the study.

\subsection{Concrete Tile Surface Temperature $\left(T_{t}\right)$}

$T_{t}$ affects the downward heat flux transmitted to the interior space, hence the electrical energy use for heating and cooling. The impact of green roofs on $T_{t}$ tends to be dual, decreasing during daytime on sunny and cloudy days of the four seasons, while increasing on other occasions (Figure 5). The daytime $T_{t}$ reduction is more notable on sunny days than cloudy days in terms of magnitude and significant level. For instance, the sunny daytime $T_{t}$ was significantly reduced by $4.1{ }^{\circ} \mathrm{C}, 2.7{ }^{\circ} \mathrm{C}, 4.9{ }^{\circ} \mathrm{C}$, and $4.3^{\circ} \mathrm{C}$, respectively for spring, summer, fall, and winter ( $p<0.01$ for the four seasons), contrasting equivalent values of cloudy days were $2.1^{\circ} \mathrm{C}(p<0.01), 1.4^{\circ} \mathrm{C}(p<0.01), 2.9^{\circ} \mathrm{C}(p<0.01)$, and $0.7{ }^{\circ} \mathrm{C}(p>0.05)$. The results indicate a notable decrease in cooling load on sunny and cloudy daytime through the year, with higher energy saving on sunny days.

In contrast, the nocturnal $T_{t}$ is significantly increased for all weather types of the four seasons except FLC. The nocturnal increase plays contradictive roles in different seasons. In summer time, increased $T_{t}$ impedes heat loss from the interior space, implying potential negative impacts of green roofs in uplifting electrical energy use for space cooling. In spring and fall when the space-conditioning is absent, the increase of $T_{t}$ has limited implication for energy consumption. In winter when warming is desirable, the rise of $T_{t}$ can, instead, trim energy use for space warming. The above results suggest potential trade-offs associated with green-roof installation in humid-tropical Hong Kong with positive impacts sometimes and negative on other occasions. The energy-saving of green roofs should be estimated based on net effects considering both daytime cooling and nocturnal warming. 

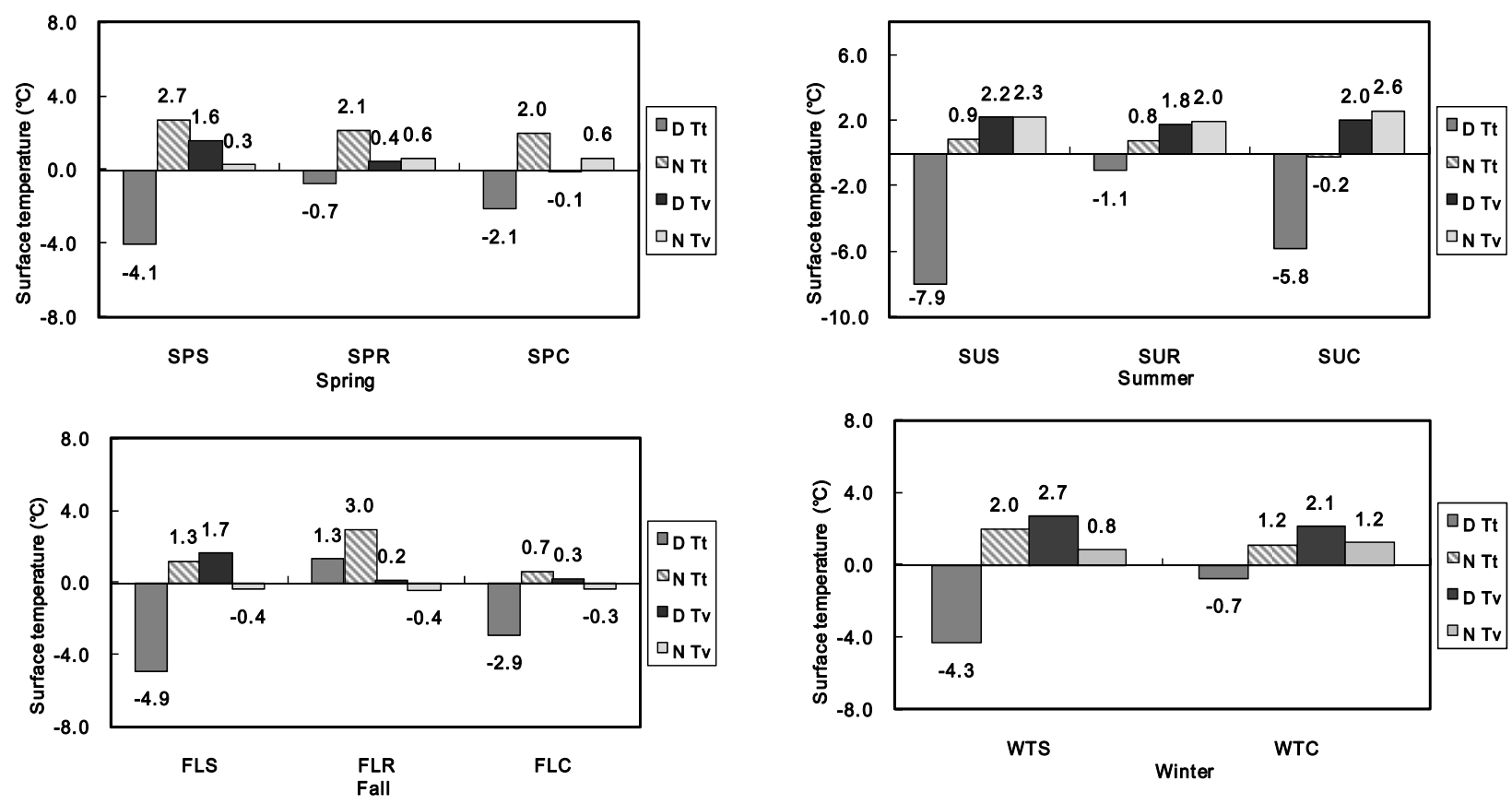

Figure 5. Modification of surface temperature after roof greening for the four seasons.

\section{Thermal-Effect Prediction Models}

The multiple regression analysis finds notable impacts of background weather parameters on green-roof thermal effects (Table 5). Overall, the five weather parameters SR, Ta, RH, WS, and SM could explain around $83.6 \%-86 \%\left(R^{2}=0.7-0.74\right)$ of the daytime and nighttime thermal effects' variation. $T_{a}$ is the most significant explanatory variable as it has the highest Beta value in all of the eight models. $\mathrm{RH}$ is second to $T_{a}$ in explaining the thermal-effect variations of DT $T_{10}$, DT $T_{v}$, and DT $\mathrm{RH}_{10}$. SR could significantly affect the daytime thermal effects, while WS appears to be more significant in impacting the nighttime thermal effects. SM is the least important weather factor for green-roof thermal performance.

Of the four thermal-effect indicators, $\mathrm{T}_{10}$ and $T_{v}$ are more sensitive to background weather parameters than the other two. This might lead to the conclusion that background weather conditions affect cooling effects more than energy-saving effects of green roofs.

Based on the multiple regression models, green-roof thermal effects can be predicted by background weather parameters using the following eight equations (where *denotes that the correlation is significant at the 0.05 level, and ${ }^{* *}, 0.01$ level):

$$
\begin{aligned}
& D T \cdot T_{10}=-0.001^{\prime \prime \prime}(\mathrm{SR})-0.15^{* \prime \prime}(T a)-0.03^{\prime \prime \prime}(\mathrm{RH})-0.3^{*}(\mathrm{WS})+0.03^{* *}(S M)+4.1^{* *} \\
& N T \cdot T_{10}=-0.14^{* *}(T a)+0.02^{* *}(R H)+0.39^{* * *}(W S)+0.03^{*}(S M)-1.3^{* *} \\
& D T \cdot R H_{10}=0.4^{\prime \prime \prime}(T a)+0.11^{\prime \prime \prime}(\mathrm{RH})+0.005^{\prime \prime \prime}(S R)-0.07^{\prime \prime \prime}(S M)+0.56^{\circ}(\mathrm{WS})-15.1 \\
& D T \cdot R H_{10}=0.45^{* *}\left(T_{a}\right)-0.07^{* *}(S M)-1.2^{* *}(\mathrm{WS})-2.5 \\
& D T \cdot T_{t}=-0.19^{* * *}\left(T_{a}\right)+0.08^{* *}(\mathrm{RH})-0.01^{* *}(S R)+0.59^{*}(W S)-3.5
\end{aligned}
$$




$$
\begin{gathered}
N T \cdot T_{t}=-0.08^{* *}\left(T_{a}\right)-0.03^{* *}(S M)+4.3 \\
D T \cdot T_{V}=-0.17^{7^{*}}\left(T_{a}\right)-0.03^{* *}(\mathrm{RH})-0.002^{* *}(S R)+0.05^{* *}(S M)-0.4^{* *}(\mathrm{WS})+5.7 \\
N T \cdot T_{V}=-0.15^{* *}\left(T_{a}\right)+0.23^{* *}(W S)+0.02^{* *}(R H)+1.5
\end{gathered}
$$

\begin{tabular}{|c|c|c|c|c|c|c|c|c|}
\hline \multirow{2}{*}{$\begin{array}{l}\text { Weather parameter } \\
\text { /thermal indicator }\end{array}$} & \multicolumn{2}{|c|}{$\mathbf{T}_{10}$} & \multicolumn{2}{|c|}{$T_{t}$} & \multicolumn{2}{|c|}{$\mathbf{T}_{\mathbf{v}}$} & \multicolumn{2}{|c|}{$\mathbf{R H}_{\mathbf{1 0}}$} \\
\hline & DT & NT & DT & NT & DT & NT & DT & NT \\
\hline SR & $\begin{array}{c}-0.001^{* *} \\
(-0.16)\end{array}$ & - & $\begin{array}{l}-0.01^{* *} \\
(-0.48)\end{array}$ & - & $\begin{array}{c}-0.002^{* *} \\
(-0.17)\end{array}$ & - & $\begin{array}{c}0.005^{* *} \\
(0.22)\end{array}$ & - \\
\hline $\mathrm{T}_{\mathrm{a}}$ & $\begin{array}{l}-0.15^{* *} \\
(-0.62)\end{array}$ & $\begin{array}{l}-0.14^{* *} \\
(-0.84)\end{array}$ & $\begin{array}{l}-0.19^{* *} \\
(-3.43)\end{array}$ & $\begin{array}{l}-0.08^{* *} \\
(-0.30)\end{array}$ & $\begin{array}{l}-0.17^{* *} \\
(-0.59)\end{array}$ & $\begin{array}{l}-0.15^{* *} \\
(-0.90)\end{array}$ & $\begin{array}{l}0.40^{* *} \\
(0.59)\end{array}$ & $\begin{array}{l}0.45^{* *} \\
(0.80)\end{array}$ \\
\hline RH & $\begin{array}{l}-0.03^{* *} \\
(-0.29) \\
\end{array}$ & $\begin{array}{l}0.02^{* *} \\
(0.19)\end{array}$ & $\begin{array}{l}0.08^{* *} \\
(0.35)\end{array}$ & - & $\begin{array}{c}-0.03^{* *} \\
(-0.3)\end{array}$ & $\begin{array}{l}0.02^{* *} \\
(0.18)\end{array}$ & $\begin{array}{l}0.11^{* *} \\
(0.40)\end{array}$ & - \\
\hline WS & $\begin{array}{l}-0.3^{* *} \\
(-0.14) \\
\end{array}$ & $\begin{array}{l}0.39^{* *} \\
(0.32)\end{array}$ & $\begin{array}{l}0.59^{* *} \\
(0.11)\end{array}$ & - & $\begin{array}{l}-0.4^{* *} \\
(-0.14) \\
\end{array}$ & $\begin{array}{l}0.23^{* *} \\
(0.19) \\
\end{array}$ & $\begin{array}{l}0.56^{*} \\
(0.09) \\
\end{array}$ & $\begin{array}{l}-1.20^{* *} \\
(-0.30) \\
\end{array}$ \\
\hline SM & $\begin{array}{l}0.03^{* *} \\
(-0.15) \\
\end{array}$ & $\begin{array}{l}0.03^{* *} \\
(0.16) \\
\end{array}$ & - & $\begin{array}{l}-0.03^{*} \\
(-0.13) \\
\end{array}$ & $\begin{array}{l}0.05^{* *} \\
(0.17) \\
\end{array}$ & - & $\begin{array}{l}-0.07^{* *} \\
(-0.11) \\
\end{array}$ & $\begin{array}{l}-0.07^{* *} \\
(-0.14) \\
\end{array}$ \\
\hline Constant & 4.14 & -1.25 & -3.5 & 4.29 & 5.73 & 1.47 & -15.1 & -2.5 \\
\hline$R^{2}$ & 0.72 & 0.73 & 0.72 & 0.08 & 0.72 & 0.7 & 0.74 & 0.72 \\
\hline
\end{tabular}

Table 5. Multiple regression models for predicting green-roof thermal effects by background weather parameters.

Note: Two predictive models, DT and NT, were established for each thermal-effect indicator; the determination coefficients $\left(R^{2}\right)$ represent the percentage of the variation in thermal indicators that can be explained by the regression models; the standardized coefficients (Beta value in parentheses) represent the relative contributions of different weather parameters to thermal effects.

\section{Conclusions}

Based on monitoring data of the railway station extensive green roof, we investigated the diurnal and seasonal patterns of green-roof thermal performance. Compared with previous field experiments, which focused on a few sunny summer days, we evaluated thermal performance in relation to key meteorological parameters and 11 weather scenarios covering a whole-year cycle.

Green-roof thermal performance demonstrated notable seasonal, diurnal, and vertical patterns. It had cooling effects in spring, summer, and fall, with slight warming effects in winter. The cooling effects were more pronounced in summer than spring and fall, on sunny days than rainy and cloudy days, and in nighttime than daytime. The result of higher nocturnal cooling effects is consistent with Speak et al.'s study, which also found that across a day strongest cooling occurs at night [38]. However, the effects were mostly restricted to limited distance. At $160 \mathrm{~cm}$ above the roof surface, the modification of ambient air temperature became insignificant.

The multiple regression analyses found that background weather parameters contribute significantly to green-roof thermal effects and, thus, are a major cause of seasonal and diurnal variations of thermal performance. The five weather parameters (SR, $T_{a}$, RH, WS, and SM) could explain $83.6 \%-86 \%$ of the 
thermal effects' variation. Our experimental site represents a typical extensive green roof (evergreen herbaceous plants) established on low-rise structures in low-density urban settings. The multiple-regression models established in this study might help to predict the thermal performance of extensive green roofs in subtropical areas.

\section{Acknowledgments}

This research is supported by the National Natural Science Foundation of China (Grant No. 41401179), the Natural Science Foundation of Jiangsu Province, China (Grant No. BK20140941) and the Natural Science Foundation of the Jiangsu Province Higher Education Institutions (Grant No. 14KJB170006). The kind help offered by Jeannette Liu, Raymond Wai Hung Law and Iris Hui Juan Deng are gratefully appreciated.

\section{Author Contributions}

C. Y. Jim conceived and designed the experiment; Lilliana. L. H. Peng conducted the experiment, performed the data analysis and wrote the manuscript.

\section{Conflicts of Interest}

The authors declare no conflict of interest.

\section{References}

1. Demuzere, M.; Orru, K.; Heidrich, O.; Olazabal, E.; Geneletti, D.; Orru, H.; Bhave, A.G.; Mittal, N.; Feliu, E.; Faehnle, M. Mitigating and adapting to climate change: Multi-functional and multi-scale assessment of green urban infrastructure. J. Environ. Manag. 2014, 146, 107-115.

2. Hallegatte, S.; Corfee-Morlot, J. Understanding climate change impacts, vulnerability and adaptation at city scale: An introduction. Clim. Change 2011, 104, 1-12.

3. Pisello, A.L.; Piselli, C.; Cotana, F. Thermal-physics and energy performance of an innovative green roof system: The Cool-Green Roof. Sol. Energy 2015, 116, 337-356.

4. Gao, Y.; Xu, J.; Yang, S.; Tang, X.; Zhou, Q.; Ge, J.; Xu, T.; Levinson, R. Cool roofs in China: Policy review, building simulations, and proof-of-concept experiments. Energy Policy 2014, 74, 190-214.

5. Gilbert, H.; Mandel, B.H.; Levinson, R. Keeping California cool: Recent cool community developments. Energy Build. 2015, doi:10.1016/j.enbuild.2015.06.023.

6. Salata, F.; Golasi, I.; Vollaro, A.D.L.; Vollaro, R.D.L. How high albedo and traditional buildings' materials and vegetation affect the quality of urban microclimate. A case study. Energy Build. 2015, 99, 32-49.

7. Jim, C.Y.; Peng, L.L.H. Weather effect on thermal and energy performance of an extensive tropical green roof. Urban For. Urban Green. 2012, 11, 73-85.

8. Peng, L.L.H.; Jim, C.Y. Economic evaluation of green-roof environmental benefits in the context of climate change: The case of Hong Kong. Urban For. Urban Green. 2015, 14, 554-561.

9. Onmura, S.; Matsumoto, M.; Hokoi, S. Study on evaporative cooling effect of roof lawn gardens. Energy Build. 2001, 33, 653-666. 
10. Wong, N.H.; Chen, Y.; Ong, C.L.; Sia, A. Investigation of thermal benefits of rooftop garden in the tropical environment. Build. Environ. 2003, 38, 261-270.

11. Sonne, J.K. Evaluating Green Roof Energy Performance. ASHRAE J. 2006, 48, 59-61.

12. Wong, N.H.; Puay Yok, T.; Yu, C. Study of thermal performance of extensive rooftop greenery systems in the tropical climate. Build. Environ. 2007, 42, $25-54$.

13. Santamouris, M.; Pavlou, C.; Doukas, P.; Mihalakakou, G.; Synnefa, A.; Hatzibiros, A.; Patargias, P. Investigating and analyzing the energy and environmental performance of an experimental green roof system installed in a nursery school building in Athens, Greece. Energy 2007, 32, 1781-1788.

14. Simmons, M.T.; Gardiner, B.; Windhager, S.; Tinsley, J. Green roofs are not created equal: the hydrologic and thermal performance of six different extensive green roofs and reflective and non-reflective roofs in a sub-tropical climate. Urban Ecosyst. 2008, 11, 339-348.

15. Spala, A.; Bagiorgas, H.S.; Assimakopoulos, M.N.; Kalavrouziotis, J.; Matthopoulos, D.; Mihalakakou, G. On the green roof system. Selection, state of the art and energy potential investigation of a system installed in an office building in Athens, Greece. Renew. Energy 2008, 33, 173-177.

16. Spolek, G. Performance monitoring of three ecoroofs in Portland, Oregon. Urban Ecosyst. 2008, 11, 349-359.

17. Eumorfopoulou, E.A.; Kontoleon, K.J. Experimental approach to the contribution of plant-covered walls to the thermal behaviour of building envelopes. Build. Environ. 2009, 44, 1024-1038.

18. Teemusk, A.; Mander, U. Greenroof potential to reduce temperature fluctuations of a roof membrane: A case study from Estonia. Build. Environ. 2009, 44, 643-650.

19. Jim, C.Y.; Peng, L.L.H. Substrate moisture effects on water balance and thermal performance of a tropical green roof. Eco. Eng. 2012, 47, 9-23.

20. Jim, C.Y. Air-conditioning energy consumption due to green roofs with different building thermal insulation. Appl. Energy 2014, 128, 49-59.

21. Jim, C.Y. Building thermal-insulation effect on ambient and indoor thermal performance of green roofs. Ecol. Eng. 2014, 69, 265-275.

22. Luo, H.; Wang, N.; Chen, J.P.; Ye, X.Y.; Sun, Y.F. Study on the thermal effects and air quality improvement of green roof. Sustainability 2015, 7, 2804-2817.

23. Kokogiannakis, G.; Darkwa, J. Support for the integration of green roof constructions within Chinese building energy performance policies. Energy 2014, 65, 71-79.

24. Kumar, R.; Kaushik, S.C. Performance evaluation of green roof and shading for thermal protection of buildings. Build. Environ. 2005, 40, 1505-1511.

25. Alexandri, E.; Jones, P. Developing a one-dimensional heat and mass transfer algorithm for describing the effect of green roofs on the built environment: comparison with experimental results. Build. Environ. 2007, 42, 2835-2849.

26. Sailor, D. A green roof model for building energy simulation programs. Energy Build. 2008, 40, 1466-1478.

27. Sun, T.; Bou-Zeid, E.; Ni, G.H. To irrigate or not to irrigate: Analysis of green roof performance via a vertically-resolved hygrothermal model. Build. Environ. 2014, 73, 127-137. 
28. Klein, P.M.; Coffman, R. Establishment and performance of an experimental green roof under extreme climatic conditions. Sci. Total. Environ. 2015, 512-513, 82-93.

29. Bass, B.; Krayenhoff, S; Martilli, A.; Stull, R. Mitigating the urban heat island with green roof infrastructure. Urban Heat Isl. Summit 2002, doi:10.12944/CWE.10.Special-Issue1.111.

30. Banting, D.; Doshi, H.; Li, J.; Missios, P.; Au, A.; Currie, B.A.; Verrati, M. Report on the Environmental Benefits and Costs of Green Roof Technology for the City of Toronto; Ryerson University: Toronto, ON, Canada, 2005.

31. Savio, P.; Rosenzweig, C.; Solecki, W.D.; Slosberg, R.B. Mitigating New York City's Heat Island with Urban Forestry, Living Roofs, and Light Surfaces. New York City Regional Heat Island Initiative; The New York State Energy Research and Development Authority: Albany, NY, USA, 2006.

32. Smith, K.; Roeber, P. Green roof mitigation potential for a proxy future climate scenario in Chicago, Illinois. J. Appl. Meteorol. Clim. 2011, 50, 507-522.

33. Chan, A.L.S.; Chow, T.T. Energy and economic performance of green roof system under future climatic conditions in Hong Kong. Energy Build. 2013, 64, 182-198.

34. Virk, G.; Jansz, A.; Mavrogianni, A.; Mylona, A.; Stocker, J.; Davies, M. Microclimatic effects of green and cool roofs in London and their impacts on energy use for a typical office building. Energy Build. 2015, 88, 214-228.

35. Raji, B.; Tenpieric, M.J.; Dobbelsteen, A.V.D. The impacts of greening systems on building energy performance: A literature review. Renew. Sustain. Energy Rev. 2015, 45, 610-623.

36. Santamouris, M. Cooling the cities- A review of reflective and green roof mitigation technologies to fight heat island and improve comfort in urban environments. Sol. Energy 2014, 103, 682-703.

37. Coutts, A. M.; Beringer, J.; Tapper, N.J. Impact of increasing urban density on local climate: spatial and temporal variations in the surface energy balance in Melbourne, Australia. J. Appl. Meteorol. Clim. 2007, 46, 477-493.

38. Speak, A.F.; Rothwell, J.J.; Lindley, S.J.; Smith, C.L. Reduction of the urban cooling effects of an intensive green roof due to vegetation damage. Urban Clim. 2013, 3, 40-55.

39. Siu, L.W. Quantifying the Urban Heat Island (UHI) Intensity in Hong Kong. MPhil Thesis, The University of Hong Kong, Hong Kong, China, 2011.

40. Tian, Y.H.; Jim, C.Y. Development potential of sky gardens in the compact city of Hong Kong. Urban For. Urban Green. 2012, 11, 223-233.

41. Tian, Y.H.; Jim, C.Y.; Tao, Y. Challenges and Strategies for Greening the Compact City of Hong Kong. J. Urban. Plan. Dev. 2012, 138, 101-109.

42. Peng, L.L.H.; Jim, C.Y. Green-roof effects on neighborhood microclimate and human thermal sensation. Energies 2013, 6, 598-618.

43. Shan, X.Z.; Yu, X.J. Citizen assessment as policy tool of urban public services, empirical evidence from assessment of urban green spaces in China. Sustainability 2014, 6, 7833-7849.

(C) 2015 by the authors; licensee MDPI, Basel, Switzerland. This article is an open access article distributed under the terms and conditions of the Creative Commons Attribution license (http://creativecommons.org/licenses/by/4.0/). 